\title{
Input and Output Driven Sales Personnel Performance Measures: Insights from an Experiment
}

\author{
H.R. Ganesha ${ }^{1}$, P.S. Aithal ${ }^{2}$, \&P. Kirubadevi ${ }^{3}$ \\ ${ }^{1}$ Chief Executive Officer - Consulting Division, Gramss Retail Trading Private Limited, \\ Bengaluru - 560078, India and Post-Doctoral Research Fellow, College of Management\& \\ Commerce, Srinivas University, Mangalore - 575001, India. \\ OrcidID: 0000-0002-5878-8844; E-mail: hrganesha@yahoo.co.in \\ ${ }^{2}$ Vice Chancellor, Srinivas University, Mangalore - 575001, India. \\ OrcidID: 0000-0002-4691-8736;E-mail: psaithal@gmail.com \\ ${ }^{3}$ Head of Category Management and Sourcing, Actoserba Active Wholesale Private Limited \\ (Zivame), Bengaluru - 560038, India. \\ OrcidID: 0000-0003-2291-8448; E-mail: spkirubadevi@yahoo.com
}

Area of the Paper: Business Management.

Type of the Paper: Research Paper.

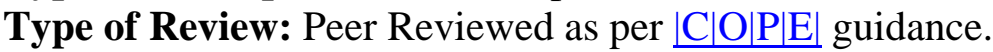

Indexed In: OpenAIRE.

DOI: http://doi.org/10.5281/zenodo.3764555.

Google Scholar Citation: IJCSBE.

\section{How to Cite this Paper:}

Ganesha, H. R., Aithal, P. S., \& Kirubadevi, P. (2020). Input and Output Driven Sales Personnel Performance Measures: Insights from an Experiment. International Journal of Case Studies in Business, IT, and Education (IJCSBE), 4(1), 23-37.

DOI: http://doi.org/10.5281/zenodo.3764555.

International Journal of Case Studies in Business, IT and Education (IJCSBE)

A Refereed International Journal of Srinivas University, India.

(C) With Authors.

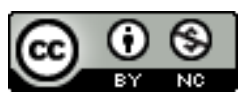

This work is licensed under a Creative Commons AttributionNon-Commercial 4.0 International License subject to proper citation to the publication source of the work.

Disclaimer: The scholarly papers as reviewed and published by the Srinivas Publications (S.P.), India are the views and opinions of their respective authors and are not the views or opinions of the S.P. The S.P. disclaims of any harm or loss caused due to the published content to any party. 


\title{
Input and Output Driven Sales Personnel Performance Measures: Insights from an Experiment
}

\author{
H. R. Ganesha ${ }^{1}$, P. S. Aithal ${ }^{2}$, \& P. Kirubadevi ${ }^{3}$ \\ ${ }^{1}$ Chief Executive Officer - Consulting Division, Gramss Retail Trading Private Limited, \\ Bengaluru - 560078, India and Post-Doctoral Research Fellow, College of Management\& \\ Commerce, Srinivas University, Mangalore - 575001, India. \\ OrcidID: 0000-0002-5878-8844; E-mail: hrganesha@yahoo.co.in \\ ${ }^{2}$ Vice Chancellor, Srinivas University, Mangalore - 575001, India. \\ OrcidID: 0000-0002-4691-8736;E-mail: psaithal@gmail.com \\ ${ }^{3}$ Head of Category Management and Sourcing, Actoserba Active Wholesale Private Limited \\ (Zivame), Bengaluru - 560038, India. \\ OrcidID: 0000-0003-2291-8448; E-mail: spkirubadevi@yahoo.com
}

\begin{abstract}
It is a globally accepted strategy that, retaining existing consumers is significantly cost effective than focussing on acquiring new consumers. In brick-and-mortar retailing, sales personnel play the most important and complex role whereby they are the ones who are connected to consumers directly on a real-time basis. It is observed that the majority of brick-and-mortar retailers in India use measures to measure sales personnel performance which is mathematically derived numbers viz. average transaction value (ATV), average basket size (ABS) and contribution margin percentage (GM\%) and these are all output driven measures. Such output driven measures are making the sales personnel's role furthermore complex and in turn, their focus is expected to have shifted from consumer needs to these output driven measures set by their management. In this research, we have carried out an experiment using input driven measures viz. category invoice penetration (CIP) and invoices/bills generated by the sales personnel per day and evaluated the change in (a) sales personal attitude towards consumer orientation and (b) overall store profitability.
\end{abstract}

Keywords: Brick-and-mortar store, Offline store, Physical store, Salespeople, Salesperson, Sales personnel, Customer orientation, Sales Personnel Performance.

\section{INTRODUCTION :}

Multi-category and multi-branded retail store comprise of many products/categories which cater to specific needs consumers. Most of the retailers, classify these products into different sections either based on consumer needs (demand side) or product's behaviour (supply side) or visual appeal (communication side) and this classification is known as categories. Each of these categories includes at least twenty-five sub-categories and each sub-category will comprise minimum hundred variants and every product/category play an important role with respect to consumer and retailer. It is imperative to note that, the understanding of the role played by a particular product/category might not be same among consumers, retailers and sales personnel. What is really important and of significant essence is that every salesperson in the store is familiar with each of these product/category roles in relation to consumer store visit frequency and utilize this knowledge to enhance their own performance in a sagacious manner thereby enhancing (a) overall consumer repeat store visit frequency, (b) overall store profitability and (c) their individual performance.

\section{LITERATURE REVIEW :}

Weitz (1979) [1], believes that the way in which sales personnel interact with consumers needs to be customized to each consumer and this could possibly be able to determine their success. Saxe and Weitz (1982) [2], were the first to define sales personnel's consumer orientation. This customer 
orientation is said to happen when the sales personnel and consumer together practice the marketing concept. They have clearly stated that just the interaction between sales personnel and consumer does not yield to this orientation, it needs to encompass most of the marketing concepts driven centrally by the company. Later, Brown et al. (2002) [3] narrowed down this definition and came up with two key constructs, the first one being sales personnel's tendency to ensure consumer needs are met and the second one being the level of sales personnel's enjoyment in doing so. Vandewalle et al. (1999) [4], what can lead to sales personnel enjoy the process of interaction with consumers and ultimately selling a product is their strong orientation to learning.

Jackson et al. (1983) [5], while reviewing the issues relating to sales personnel performance measures noted that supervisors managing the sales personnel always emphasized on qualitative measures rather than quantitative measures. In their study, this emphasis was confirmed by responses to the question, 'What five factors do you use and consider being most important in the evaluation of salespeople?' Criteria named most often included four qualitative bases viz, (a) attitude, (b) aggressiveness, (c) judgment/decision-making ability, and (d) planning and only one quantitative measure were included which is the overall sales by the sales personnel.

David M. Holley (1986) [6], developed a framework for evaluating the morality of various sales practices and key the moral issues discussed were(a) sales activities, (b) a market system of production and distribution. Such systems are generally used for successful achievement of key goals.

Lawrence et al. (1986) [7], presented that measures of performance have been conventional form i.e. use of a single-source type in an appraisal system. The researcher tested role conflict \& role ambiguity and its effects on performance congruence.

Alan et al. (1989) [8], the study explored the causal attributions sales managers make of a salesperson's performance in a situation (i.e., failure to obtain a sale), as well as the responses sales managers might take. The paper examines the performance evaluation of salespeople by attribution theory and tried to measure internal (dispositional) or external (situational) attributions for an employee's performance. Gentry et al. (1991) [9], developed a model for salesforce evaluation which provides a framework to identify the common biases affecting the expectations of the sales manager and how one can mitigate the effects of the use of sub-optimal decision heuristics, and propositions. Kenneth R et al. (1992) [10], measured the relative influence of sales performance expectations of service personnel. The results indicate that in a retail sales context with moderate sales incentives, customer perceptions of the service transaction experience and satisfaction are influenced, Further, management's overall performance evaluation of service/sales personnel was found to emphasize different aspects of the service transaction experience than those used by the customer in deriving their satisfaction with the service firm. Babakus et al. (1996) [11], developed a conceptual model and examined the relationships among the sales management control system, sales territory design, salesforce behaviour and outcome performance, and sales organization effectiveness.

Each product in a store belongs to different categories and each category plays a different role for the retailer or retail store. Retailer needs to clearly understand these varied roles of different categories in relation to their key deliverables to the overall business. It was recommended by Levy, Weitz (2008) [12] and Berman, Evans (2009) [13], that, 'the fundamental principle of merchandise management involves identification of the key categories of merchandise (say yellow, orange and white goods) for any retail store; ascertain their purpose (say, crowd puller, staple and impulse) and subsequently develop the procurement as well as the delivery plan along with the planogram of the stores under consideration'.

Bryan Lilly et al. (2002) [14], presented in their research that sales managers are poor evaluators on objective sales problems which are uncontrollable and recommended that sales managers should systematically measure and track various controllable and less controllable factors that apply to their business, relate them to performance, and then think about how to improve performance on the factors most related to performance.

Wachner et al. (2009) [15], focused on SOCO (sales orientation/customer orientation) is a vital cornerstone upon which the success of salespeople is predicated in terms of serving their customers and prospects. The authors argue that customer orientation should be the predictor of sales performance. 
Mishra (2011) [16], all the stakeholders in the retail industry together or individually fail to understand and explain the retail productivity. Majority of retail stores in India operate with a lower efficiency level. Mishra also suggested that 'both independent, as well as dependent variables, need to be re-examined and modified based on theoretical as well as field level inputs.'

Miao C.F et al. (2012) [17], investigate the combinatory effects of three well-established formal sales control styles: outcome, capability, and activity control. Drawing on Expectancy Theory and Cognitive Evaluation Theory, the authors theorize that sales control combinations have differential impacts on three key intermediary variables (salesperson knowledge, role ambiguity, and intrinsic motivation), which subsequently affect salesperson performance.

From the past research findings and literature available, we could not find any simplified models/frameworks based on input driven measures which is executable in the management practice. Thus, we decided to carry out a long-term experiment using new input driven measures to evaluate the implications of input driven measures to evaluate sales personnel performance which can lead to an increase in overall store performance alongside enhancing the enjoyment level of sales personnel while attempting to build a higher level of consumer orientation.

\section{OBJECTIVES :}

Key objectives of this research were to;

(a) understand the changein overall store profitability through an experiment implementing a decentralized discounting framework across;

i. control group

ii. experimental group

iii. pre-test period

iv. post-test period

(b) draw insights from the experimentation

\section{METHODOLOGY :}

Stage I: One organized Brick-and-mortar retailer in India was selected who is having stores all over India across (a) mall stores, (b) high-street stores (c) neighbourhood stores (d) tier 1, 2 and 3 cities, (e) offering multiple-categories and multiple-brands at mid to high price positioning catering to pregnant women, new moms, babies, infants and kids up to 8 years. 15 percent of these stores were exposed to the experimentation (experimental group) and other stores were not (control group).

Stage II: Quantitative data for all the stores were collected prior to experimentations (pre-test). An open-ended personal interview was conducted for randomly selected (convenience sampling) sales personnel across experimental and control group stores to understand their understanding and attitude towards existing performance measures.

Stage III: Training session was conducted to all the sales personnel including store managers, area sales managers, territory managers, regional managers and the national sales head to impart knowledge about the new measures, their pros and cons, implementation techniques and importantly the key goal of the experimentation. Post-training the new performance measures were implemented across all the stores selected for experimentation over a period of eleven months (experimental phase).

Stage IV: Results obtained during the experimentation stage (post-test) analysed using appropriate statistical methods and compared with the pre-test period.

Stage V: The findings from this experimentation were compared with pre-test across experimental and control groups.

Stage VI: In this stage, insights and inferences from the research findings were used to propose a way forward for Brick-and-mortar retailers to enable them to design appropriate sales personnel performance measures.

\section{NEW INPUT DRIVEN MEASURES :}

1. Category Invoice Penetration: This measure is helpful in getting the sales personnel to focus on categories which are proven to be the key drivers for consumer repeat store visit frequency. Majority of marketers, researchers, academicians and management practitioners 
across the world have unanimously agreed that customer retention is one of the main components of sustainable business growth and profit. Category invoice penetration (CIP) is a new measurement tool which is rarely used by retailers in India. It is defined as, number of point of sale invoices/bills a particular category is present with respect to the total point of sale invoices/bills of a store for a given period. The total CIP of all the categories put together shall not add up to 100 percent and the same is always greater than 100 percent. Let category invoice penetration be 'CIP', category is 'A', number of invoices/bills category ' $A$ ' is present is 'NA' and Total invoices/bills of a store for a given period is NT, then;

$$
\text { CIP of } A=\frac{\text { NA }}{\text { NT }} \times 100
$$

For example; let us assume that there are two categories (books and pens) in a store. The store on the $12^{\text {th }}$ of September makes a total of $80(\mathrm{NT})$ invoices/bills. Out of these 35 invoices/bills books category ('A') products were part of 60 invoices/bills (NA) and pens category ('B') products were present in 50 invoices/bills (NB). Therefore, using the CIP formula shown above CIP of ' $A$ ' is 75.00 percentage whereas CIP of category ' $B$ ' is 62.50 percent. You can see that the total CIP of category A and B on $12^{\text {th }}$ September is not less than $100 \%$ and also does not adds up to 100 percent.

2. Bills per day per sales personnel: This measure is to motivate sales personnel to convert as many walk-ins to a transaction/invoice/bill as possible and forget about everything else.

\section{KEY FINDINGS AND INSIGHTS :}

\section{Control group;}

- key performance indicators of sales personnel performance were;

0 average basket size (ABS)

0 average transaction value (ATV)

o gross earning percentage (GM\%)

- sales personnel understanding and attitude towards performance measures;

o sell higher priced products

o transaction is more important than the consumer's life-time value (current bill)

o ignore walk-ins who enquires for a low value product (reduces ATV)

0 essential products have low ticket value (reduces ATV)

o non-essential products have high ticket value (increases ATV)

o avoid giving discounts (reduces GM\%)

o avoid walk-ins who are intending to buy just one item (reduces ABS)

\section{Experimental group;}

- $\quad$ key performance indicators of sales personnel performance were;

0 category invoice penetration of essential products (CIP)

o convert every walk-in to transactions and finally consumer of only your store for a longer period of time

- sales personnel understanding and attitude towards performance measures (post-training and before experimentation);

o do not ignore any walk-ins, selling and conversion is important irrespective of value and volume of the products/brands/categories walk-ins are looking for

o consumer's life-time value is more important than this particular transaction

o essential products are daily needs of the consumer and can potentially get the consumer to store more frequently

o non-essential products to be used as key cross-selling and up-selling items without too much of push to the consumer

o discount is one of the key components of selling and consumer engagement proposition as consumers have competitive knowledge about discounts, especially online stores 
Using pre-test post-test control group formula, we have found that the real treatment effect has shown a 3.541 times improvement in the overall store profitability of the experimental group over their pretest period which is significant. Comparative results as shown in table 1, 2, and 3when compared with different periods indicate that the measures used in evaluating sales personnel which are the key directives for them to perform in a standard manner have indicated a direct impact on the category invoice penetration of essential products and by the virtue of essential products being lower in value, the average transaction values have shown significant change thereby impacting the overall store profitability.

Quantitative results clearly indicate;

i. a negative correlation between CIP and ATV across experimental (-0.053 pre-test and -0.590 post-test) and control group (-0.032 pre-test and -0.415 post-test) during pre-test and post-test periods. Even though it is not significant, they are negatively correlated,

ii. a positive correlation between ATV and average bills per day per square foot in the experimental group (0.491)during pre-test period anda negative correlation (-0.534)during posttest period, whereas in the control group correlation is negative during pre and post-test periods (-0.312 pre-test and -0.286 post-test). All these correlations were not significant,

iii. a positive correlation between bills generated per day per square foot by a store and the overall store profitability across experimental ( 0.727 pre-test and 0.914 post-test) and control group (0.198 pre-test and 0.825 post-test). In the experimental group, the correlation was found to be significant during pre and post-test periods.

Table 1: Percentage change over pre-test period across each key factor for control and experimental groups post-test.

\begin{tabular}{|l|c|c|c|}
\hline Factors & $\begin{array}{c}\text { Post-Test } \\
\text { Control Group } \\
\text { (Output Driven) }\end{array}$ & $\begin{array}{c}\text { Post-Test } \\
\text { Expe riment } \\
\text { Group }\end{array}$ \\
\hline CIP of essentiven)
\end{tabular}

As far as qualitative findings are concerned an open-ended interview was conducted with all the sales personnel of the stores under experimental group and unanimously, they have all said, they felt empowered during the experimentation. They were completely out of all the tensions which used to be the case with earlier output driven measures viz, ATV, ABS and GM\%. To ensure they achieve these output driven targets they have lost many opportunities to convert many walk-ins to bills. The new input driven targets such as a) CIP and b) number of bills to be made per day were simple to understand and achieve. The key insight from these direct interviews was that, the results of this experiment were clearly visible to them as they were able to convert many walk-ins into bills, get many of these consumers return to their store more frequently which helped their store to grow the 
revenue by 69 percent and store profit by 139 percent compared to pre-test period thereby enhancing their sales incentives by multi-fold.

Table 2: Percentage change across each key factor between experimental group and control group pre-test phase.

\begin{tabular}{|l|c|}
\hline Factors & $\begin{array}{c}\text { Post-Test } \\
\text { Experiment Group } \\
\text { (Input Driven) }\end{array}$ \\
\hline CIP of essential products & $-7 \%$ \\
\hline Average MRP of essential products & $-6 \%$ \\
\hline Average selling price of essential products & $-1 \%$ \\
\hline Average transaction value of essential products & $-10 \%$ \\
\hline Average basket size of essential products & $-9 \%$ \\
\hline CIP of non-essential products & $-2 \%$ \\
\hline Average MRP of non-essential products & $-2 \%$ \\
\hline Average selling price of non-essential products & $-7 \%$ \\
\hline Average transaction value of non-essential products & $-15 \%$ \\
\hline Average basket size of non-essential products & $-9 \%$ \\
\hline Average MRP of store & $-5 \%$ \\
\hline Average selling price of store & $-3 \%$ \\
\hline Average transaction value of store & $-17 \%$ \\
\hline Average basket size of store & $-14 \%$ \\
\hline Discount per cent & $-12 \%$ \\
\hline Bills per day per square foot & $15 \%$ \\
\hline Sale quantity per day per square foot & $0 \%$ \\
\hline Revenue per day per square foot & $-4 \%$ \\
\hline Earning per day per square foot & $-1 \%$ \\
\hline Profit per day per square foot & $52 \%$ \\
\hline & \\
\hline
\end{tabular}

Table 3: Percentage change across each key factor between experimental group and control group post-test.

\begin{tabular}{|l|c|}
\hline Factors & $\begin{array}{c}\text { Post-Test } \\
\text { Experiment Group } \\
\text { (Input Driven) }\end{array}$ \\
\hline CIP of essential products & $7 \%$ \\
\hline Average MRP of essential products & $-5 \%$ \\
\hline Average selling price of essential products & $-6 \%$ \\
\hline Average transaction value of essential products & $-23 \%$ \\
\hline Average basket size of essential products & $-18 \%$ \\
\hline CIP of non-essential products & $-5 \%$ \\
\hline Average MRP of non-essential products & $-11 \%$ \\
\hline Average selling price of non- essential products & $-11 \%$ \\
\hline Average transaction value of non-essential products & $-18 \%$ \\
\hline Average basket size of non-essential products & $-8 \%$ \\
\hline Average MRP of store & $-8 \%$ \\
\hline Average selling price of store & $-8 \%$ \\
\hline Average transaction value of store & $-19 \%$ \\
\hline Average basket size of store & $-13 \%$ \\
\hline Discount per cent & $5 \%$ \\
\hline Bills per day per square foot & $39 \%$ \\
\hline Sale quantity per day per square foot & $22 \%$ \\
\hline Revenue per day per square foot & $12 \%$ \\
\hline Earning per day per square foot & $12 \%$ \\
\hline Profit per day per square foot & $339 \%$ \\
\hline
\end{tabular}




\section{CONCLUSION :}

The experiment of changing the performance measures of sales personnel from an output driven target to an input driven target has clearly shown significant improvement in the overall store's (a) number of bills, (b) sales volume, (c) revenue, (d) gross margin value and most importantly, (e) the overall store profitability and most importantly, (f) sales personnel attitude towards consumer orientation. Prior to the experimentation, it was anticipated that most of the output driven measures such as average selling price, average transaction value, average basket size, and gross margin percent will significantly degrow which was made known to the sales personnel in the experimental group of stores well in advance which was supported by the post-test results. Almost all of the output driven measures were mathematically derived numbers which could only indicate as to what could have happened, and it was just a post-mortem analysis for every sales manager and other functional heads of the retail company. On the other hand, the new measures experimented were input driven, meaning, they were all helping the sales personnel to understand the role of each product to be it essential, non-essential, high priced, low priced and so on and indirectly these measures were pushing them to focus on just the consumer, consumer's immediate needs, consumer's lifetime value rather all the time thinking about just one transaction. What we ask is what we get. If the managers ask for higher average transaction values per transaction, the sales personnel will only focus on the transaction and in doing so he/she will not have enough time to think about the consumer and consumer's lifetime value for their store. Brick-and-mortar retailers need to understand that the sales personnel are the ambassadors of the store/brand who are directly connected with the consumers on a real-time basis and any targets/measures used to evaluate the performance of sales personnel must not add on any complexity in engaging themselves with the consumers.

\section{SUGGESTIONS TO BRICK-AND-MORTAR RETAILERS :}

Based on this research outcome, we would like to suggest Brick-and-mortar retailers that they need to clearly understand (a) product/category assortment which they are offering to their target consumers, (b) role of every product/category, and (c) categorization of products such as essential (need based) or non-essential (want and demand based). Accordingly, the measures/targets need to be framed for every department across the organization which will enable every department personnel aligned to the overall organizational goal of consumer retention.

\section{LIMITATIONS OF RESEARCH :}

The main limitation of this research work is the coverage of the various stakeholders viz., consumers and retailers in experimenting with this decentralized discounting framework. This might limit the generalizability of the research findings to other set of retailers and consumers. The second limitation would be the empirical validation is restricted to one retail format i.e., multi brand and multi category baby care stores in India and hence the generalizability of the findings and suggestions to other retail formats. However, it provides significant input regarding the ways to utilise these findings as all the findings have been derived from a pre-test post-test control group experiment spread over eleven months and validated with actual empirical transactional data across different periods over a period of ten years.

\section{SCOPE FOR FURTHER RESEARCH :}

It is recommended that this research can further be extended to derive an ideal discounting framework/model for Brick-and-mortar retailers to enable them to design appropriate sales promotional programmes to effectively deal with the change in consumer's perspective towards the discount.

\section{REFERENCES :}

[1] Weitz, Barton A. (1979). A Critical Review of Personal Selling Research: The Need for Contingency Approaches, in Critical Issues in Sales Management: State-of-the-Art and Future Research Needs, Gerald Albaum and Gilbert A.Churchill, Jr. Eds. Eugene: College of Business Administration, University of Oregon, 76-126. 
[2] Saxe, Robert, and Barton A Weitz (1982). The SOCO Scale: A Measure of the Customer Orientation of Salespeople.Journal of Marketing Research, 19 (3), 343-351.

[3] Brown T.J., Mowen,J.C. Donavan,D.T. and Licata, J.W. (2002). The Customer Orientation of Service Workers: Personality Trait Effects on Self- and Supervisor Performance Ratings.Journal of Marketing Research, 34(2), 110-119.

[4] Vandewalle, Donald, Steven P. Brown, William L. Cron, and John W. Slocum (1999). The Influence of Goal Orientation and Self-Regulation Tactics on Sales Performance: A Longitudinal Field Test.Journal of Applied Psychology, 84 (2), 249-259.

[5] Jackson, Jr, Donald \& Keith, Janet \& Schlacter, John (2013). Evaluation of Selling Performance: A Study of Current Practices. Journal of Personal Selling \& Sales Management, 3. 42-51. DOI: $10.1080 / 08853134.1983 .10754357$.

[6] David M. Holley. (1986). A Moral Evaluation of Sales Practices.Business \& Professional Ethics Journal, 5(1), 3-21.

[7] Lawrence B. Chonko, RoyD. Howell and Danny N. Bellenger (1986). Congruence in Sales Force Evaluations: Relation to Sales Force Perceptions of Conflict and Ambiguity.The Journal of Personal Selling and Sales Management, 6(1), 35-48.

[8] Alan J. Dubinsky, Steven J. Skinner and Tommy E. Whittler, (1989) Evaluating Sales Personnel: An Attribution Theory Perspective. The Journal of Personal Selling and Sales Management, 9(1), 9-21.

[9] Gentry, J., Mowen, J.\& Tasaki, L. (2013). Salesperson Evaluation: A Systematic Structure for Reducing Judgmental Biases. Journal of Personal Selling \& Sales Management. 11. 27-38. DOI: 10.1080/08853134.1991.10753866.

[10] Kenneth R. Evans and John A. Grant (1992). Compensation and Sales Performance of Service Personnel: A Service Transaction Perspective. The Journal of Personal Selling and Sales Management, 12(2), 39-49.

[11] Babakus, E., Cravens, D., Grant, K., Ingram, T.\& LaForge, R. (1996). Investigating the relationships among sales, management control, sales territory design, salesperson performance, and sales organization effectiveness. International Journal of Research in Marketing. 13. 345-363. DOI: 10.1016/S0167-8116(96)00016-X.

[12] Levy Michael, Weitz Barton A. (2008).Retailing Management, Fifth Edition, Fourteenth reprint, Tata McGraw Hill. 362 - 395.

[13] Berman Barry, Evans Joel R. (2009).Retail Management, Tenth Edition, Third impression, Pearson Prentice Hall. 407 - 436.

[14] BryanLilly,ThomasW.Porter,andWilliamMeo, A.(2002).HowGoodare Managersat EvaluatingSalesProblems?Journalof PersonalSelling\&Sales Management,23(1), 51-60.

[15] Wachner, Trent, Plouffe, Christopher \& Grégoire, Yany (2009). SOCO's impact on individual sales performance: The integration of selling skills as a missing link. Industrial Marketing Management. 38. 32-44. DOI:10.1016/j.indmarman.2007.11.003.

[16] Mishra, Ashis (2011). Retail Productivity: Concept and Analysis for an Emerging Retail Sector. SSRN Electronic Journal. 10.2139/ssrn.2121113.

[17] Miao, C.F., \& Evans, K.R. (2012). Effects of formal sales control systems: A combinatory perspective. International Journal of Research in Marketing, 29(2), 181-191. DOI: https://doi.org/10.1016/j.ijresmar.2011.09.002.

$* * * * * * * * *$ 


\section{Correlations}

\section{Appendices \\ Findings}

\begin{tabular}{|c|c|c|c|c|c|}
\hline \multicolumn{6}{|c|}{ Correlations } \\
\hline Phase & Group & & & $\begin{array}{l}\text { CIP of } \\
\text { essential } \\
\text { products }\end{array}$ & $\begin{array}{c}\text { Store Average } \\
\text { Transaction } \\
\text { Value } \\
\end{array}$ \\
\hline \multirow[t]{12}{*}{ Pre-Test } & \multirow[t]{6}{*}{ Experimental } & \multirow[t]{3}{*}{ CIP of essential products } & Pearson Correlation & 1 & -.053 \\
\hline & & & Sig. (2-tailed) & & .878 \\
\hline & & & $\mathrm{N}$ & 11 & 11 \\
\hline & & \multirow{3}{*}{$\begin{array}{l}\text { Store Average } \\
\text { Transaction Value }\end{array}$} & Pearson Correlation & -.053 & 1 \\
\hline & & & Sig. (2-tailed) & .878 & \\
\hline & & & $\mathrm{N}$ & 11 & 11 \\
\hline & \multirow[t]{6}{*}{ Control } & \multirow[t]{3}{*}{ CIP of essential products } & Pearson Correlation & 1 & .032 \\
\hline & & & Sig. (2-tailed) & & .926 \\
\hline & & & $\mathrm{N}$ & 11 & 11 \\
\hline & & \multirow{3}{*}{$\begin{array}{l}\text { Store Average } \\
\text { Transaction Value }\end{array}$} & Pearson Correlation & .032 & 1 \\
\hline & & & Sig. (2-tailed) & .926 & \\
\hline & & & $N$ & 11 & 11 \\
\hline \multirow[t]{12}{*}{ Post-Test } & \multirow[t]{6}{*}{ Experimental } & \multirow[t]{3}{*}{ CIP of essential products } & Pearson Correlation & 1 & -.590 \\
\hline & & & Sig. (2-tailed) & & .056 \\
\hline & & & $\mathrm{N}$ & 11 & 11 \\
\hline & & \multirow{3}{*}{$\begin{array}{l}\text { Store Average } \\
\text { Transaction Value }\end{array}$} & Pearson Correlation & -.590 & 1 \\
\hline & & & Sig. (2-tailed) & .056 & \\
\hline & & & $\mathrm{N}$ & 11 & 11 \\
\hline & \multirow[t]{6}{*}{ Control } & \multirow[t]{3}{*}{ CIP of essential products } & Pearson Correlation & 1 & -.415 \\
\hline & & & Sig. (2-tailed) & & .204 \\
\hline & & & $\mathrm{N}$ & 11 & 11 \\
\hline & & \multirow{3}{*}{$\begin{array}{l}\text { Store Average } \\
\text { Transaction Value }\end{array}$} & Pearson Correlation & -.415 & 1 \\
\hline & & & Sig. (2-tailed) & .204 & \\
\hline & & & $\mathrm{N}$ & 11 & 11 \\
\hline
\end{tabular}

\begin{tabular}{|c|c|c|c|c|c|}
\hline \multicolumn{6}{|c|}{ Correlations } \\
\hline Phase & Group & & & $\begin{array}{c}\text { Store Average } \\
\text { Transaction } \\
\text { Value }\end{array}$ & $\begin{array}{c}\text { Bills per day } \\
\text { per square } \\
\text { foot }\end{array}$ \\
\hline \multirow[t]{12}{*}{ Pre-Test } & \multirow[t]{6}{*}{ Experimental } & \multirow{3}{*}{$\begin{array}{l}\text { Store Average } \\
\text { Transaction Value }\end{array}$} & Pearson Correlation & 1 & .491 \\
\hline & & & Sig. (2-tailed) & & .125 \\
\hline & & & $\mathrm{N}$ & 11 & 11 \\
\hline & & \multirow{3}{*}{$\begin{array}{l}\text { Bills per day per square } \\
\text { foot }\end{array}$} & Pearson Correlation & .491 & 1 \\
\hline & & & Sig. (2-tailed) & .125 & \\
\hline & & & $\mathrm{N}$ & 11 & 11 \\
\hline & \multirow[t]{6}{*}{ Control } & \multirow{3}{*}{$\begin{array}{l}\text { Store Average } \\
\text { Transaction Value }\end{array}$} & Pearson Correlation & 1 & -.312 \\
\hline & & & Sig. (2-tailed) & & .350 \\
\hline & & & $\mathrm{N}$ & 11 & 11 \\
\hline & & \multirow{3}{*}{$\begin{array}{l}\text { Bills per day per square } \\
\text { foot }\end{array}$} & Pearson Correlation & -.312 & 1 \\
\hline & & & Sig. (2-tailed) & .350 & \\
\hline & & & $\mathrm{N}$ & 11 & 11 \\
\hline \multirow[t]{12}{*}{ Post-Test } & \multirow[t]{6}{*}{ Experimental } & \multirow{3}{*}{$\begin{array}{l}\text { Store Average } \\
\text { Transaction Value }\end{array}$} & Pearson Correlation & 1 & -.534 \\
\hline & & & Sig. (2-tailed) & & .090 \\
\hline & & & $\mathrm{N}$ & 11 & 11 \\
\hline & & \multirow{3}{*}{$\begin{array}{l}\text { Bills per day per square } \\
\text { foot }\end{array}$} & Pearson Correlation & -.534 & 1 \\
\hline & & & Sig. (2-tailed) & .090 & \\
\hline & & & $\mathrm{N}$ & 11 & 11 \\
\hline & \multirow[t]{6}{*}{ Control } & \multirow{3}{*}{$\begin{array}{l}\text { Store Average } \\
\text { Transaction Value }\end{array}$} & Pearson Correlation & 1 & -.286 \\
\hline & & & Sig. (2-tailed) & & .395 \\
\hline & & & $\mathrm{N}$ & 11 & 11 \\
\hline & & \multirow{3}{*}{$\begin{array}{l}\text { Bills per day per square } \\
\text { foot }\end{array}$} & Pearson Correlation & -.286 & 1 \\
\hline & & & Sig. (2-tailed) & .395 & \\
\hline & & & $\mathrm{N}$ & 11 & 11 \\
\hline
\end{tabular}




\section{Correlations}

\begin{tabular}{|c|c|c|c|c|c|}
\hline Phase & Group & & & $\begin{array}{c}\text { Bills per day } \\
\text { per square } \\
\text { foot }\end{array}$ & $\begin{array}{c}\text { Profit per day } \\
\text { per square } \\
\text { foot }\end{array}$ \\
\hline \multirow[t]{12}{*}{ Pre-Test } & \multirow[t]{6}{*}{ Experimental } & \multirow{3}{*}{$\begin{array}{l}\text { Bills per day per square } \\
\text { foot }\end{array}$} & Pearson Correlation & 1 & $.727^{\star}$ \\
\hline & & & Sig. (2-tailed) & & .011 \\
\hline & & & $\mathrm{N}$ & 11 & 11 \\
\hline & & \multirow{3}{*}{$\begin{array}{l}\text { Profit per day per square } \\
\text { foot }\end{array}$} & Pearson Correlation & $.727^{\star}$ & 1 \\
\hline & & & Sig. (2-tailed) & .011 & \\
\hline & & & $\mathrm{N}$ & 11 & 11 \\
\hline & \multirow[t]{6}{*}{ Control } & \multirow{3}{*}{$\begin{array}{l}\text { Bills per day per square } \\
\text { foot }\end{array}$} & Pearson Correlation & 1 & .198 \\
\hline & & & Sig. (2-tailed) & & .560 \\
\hline & & & $\mathrm{N}$ & 11 & 11 \\
\hline & & \multirow{3}{*}{$\begin{array}{l}\text { Profit per day per square } \\
\text { foot }\end{array}$} & Pearson Correlation & .198 & 1 \\
\hline & & & Sig. (2-tailed) & .560 & \\
\hline & & & $\mathrm{N}$ & 11 & 11 \\
\hline \multirow[t]{12}{*}{ Post-Test } & \multirow[t]{6}{*}{ Experimental } & \multirow{3}{*}{$\begin{array}{l}\text { Bills per day per square } \\
\text { foot }\end{array}$} & Pearson Correlation & 1 & $.914^{\star \pi}$ \\
\hline & & & Sig. (2-tailed) & & .000 \\
\hline & & & $\mathrm{N}$ & 11 & 11 \\
\hline & & \multirow{3}{*}{$\begin{array}{l}\text { Profit per day per square } \\
\text { foot }\end{array}$} & Pearson Correlation & $.914^{\star \star}$ & 1 \\
\hline & & & Sig. (2-tailed) & .000 & \\
\hline & & & $\mathrm{N}$ & 11 & 11 \\
\hline & \multirow[t]{6}{*}{ Control } & \multirow{3}{*}{$\begin{array}{l}\text { Bills per day per square } \\
\text { foot }\end{array}$} & Pearson Correlation & 1 & $.825^{\star \star}$ \\
\hline & & & Sig. (2-tailed) & & .002 \\
\hline & & & $N$ & 11 & 11 \\
\hline & & \multirow{3}{*}{$\begin{array}{l}\text { Profit per day per square } \\
\text { foot }\end{array}$} & Pearson Correlation & $.825^{\mathrm{x}}$ & 1 \\
\hline & & & Sig. (2-tailed) & .002 & \\
\hline & & & $N$ & 11 & 11 \\
\hline
\end{tabular}

${ }^{\star}$. Correlation is significant at the 0.05 level (2-tailed).

**. Correlation is significant at the 0.01 level (2-tailed)

\section{Correlations}

\begin{tabular}{llr|r} 
& & \multicolumn{1}{c}{$\begin{array}{c}\text { ClP of } \\
\text { essential } \\
\text { products }\end{array}$} & $\begin{array}{c}\text { Store Average } \\
\text { Transaction } \\
\text { Value }\end{array}$ \\
\hline CIP of essential products & Pearson Correlation & 1 & -.156 \\
\cline { 2 - 4 } & Sig. (2-tailed) & 44 & .313 \\
\cline { 2 - 4 } $\begin{array}{l}\text { Store Average } \\
\text { Transaction Value }\end{array}$ & Pearson Correlation & -.156 & 44 \\
\cline { 2 - 4 } & Sig. (2-tailed) & .313 & 1 \\
\cline { 2 - 4 } & $\mathrm{N}$ & 44 & 44 \\
\hline
\end{tabular}




\section{Correlations}

\begin{tabular}{llr|r} 
& & \multicolumn{1}{c}{$\begin{array}{c}\text { Store Average } \\
\text { Transaction } \\
\text { Value }\end{array}$} & $\begin{array}{c}\text { Bills per day } \\
\text { per square } \\
\text { foot }\end{array}$ \\
\hline $\begin{array}{l}\text { Store Average } \\
\text { Transaction Value }\end{array}$ & Pearson Correlation & 1 & $-.489^{\star \star}$ \\
\cline { 2 - 4 } & Sig. (2-tailed) & 44 & .001 \\
\cline { 2 - 5 } & $\mathrm{N}$ & $-.489^{* \pi}$ & 44 \\
\hline $\begin{array}{l}\text { Bills per day per square } \\
\text { foot }\end{array}$ & Pearson Correlation & .001 & 1 \\
\cline { 2 - 5 } & Sig. (2-tailed) & 44 & 44 \\
\cline { 2 - 5 } & $\mathrm{N}$ & &
\end{tabular}

**. Correlation is significant at the 0.01 level (2-tailed).

\section{Correlations}

\begin{tabular}{|c|c|c|c|}
\hline & & $\begin{array}{l}\text { Bills per day } \\
\text { per square } \\
\text { foot }\end{array}$ & $\begin{array}{c}\text { Profit per day } \\
\text { per square } \\
\text { foot }\end{array}$ \\
\hline \multirow{3}{*}{$\begin{array}{l}\text { Bills per day per square } \\
\text { foot }\end{array}$} & Pearson Correlation & 1 & $.889^{\mathrm{x}}$ \\
\hline & Sig. (2-tailed) & & .000 \\
\hline & $N$ & 44 & 44 \\
\hline \multirow{3}{*}{$\begin{array}{l}\text { Profit per day per square } \\
\text { foot }\end{array}$} & Pearson Correlation & $.889^{\star \pi}$ & 1 \\
\hline & Sig. (2-tailed) & .000 & \\
\hline & $N$ & 44 & 44 \\
\hline
\end{tabular}

${ }^{\star *}$. Correlation is significant at the 0.01 level (2-tailed).

\section{T-Test}

\section{Paired Samples Correlations}

\begin{tabular}{|c|c|c|c|c|}
\hline & & $\checkmark$ & Correlation & Sig. \\
\hline Pair 1 & $\begin{array}{l}\text { CIP of essential products } \\
\text { \& Store Average } \\
\text { Transaction Value }\end{array}$ & 44 & -.156 & .313 \\
\hline Pair 2 & $\begin{array}{l}\text { Store Average } \\
\text { Transaction Value \& Bills } \\
\text { per day per square foot }\end{array}$ & 44 & -.489 & .001 \\
\hline Pair 3 & $\begin{array}{l}\text { Bills per day per square } \\
\text { foot \& Profit per day per } \\
\text { square foot }\end{array}$ & 44 & .889 & .000 \\
\hline
\end{tabular}




\begin{tabular}{|c|c|c|c|c|c|c|c|c|c|}
\hline \multicolumn{10}{|c|}{ Paired Samples Test } \\
\hline & & \multirow[b]{3}{*}{ Mean } & \multicolumn{3}{|c|}{ Paired Differences } & & \multirow[b]{3}{*}{$t$} & \multirow[b]{3}{*}{ df } & \multirow[b]{3}{*}{ Sig. (2-tailed } \\
\hline & & & & Std Error & $\begin{array}{r}95 \% \text { Confiden } \\
\text { Diffe }\end{array}$ & $\begin{array}{l}\text { e Interval of the } \\
\text { ence }\end{array}$ & & & \\
\hline & & & Std. Deviation & Mean & Lower & Upper & & & \\
\hline Pair 1 & $\begin{array}{l}\text { CIP of essential products } \\
\text { - Store Average } \\
\text { Transaction Value }\end{array}$ & -1623.519977 & 183.241707 & 27.624727 & -1679.230548 & -1567.809406 & -58.771 & 43 & .000 \\
\hline Pair 2 & $\begin{array}{l}\text { Store Average } \\
\text { Transaction Value - Bills } \\
\text { per day per square foot }\end{array}$ & 1624.054682 & 183.238529 & 27.624248 & 1568.345077 & 1679.764287 & 58.791 & 43 & .000 \\
\hline Pair 3 & $\begin{array}{l}\text { Bills per day per square } \\
\text { foot-Profit per day per } \\
\text { square foot }\end{array}$ & .555545 & 1.143407 & .172375 & .207918 & .903173 & 3.223 & 43 & .002 \\
\hline
\end{tabular}

\section{Regression}

\begin{tabular}{|c|c|c|c|c|c|c|c|c|c|c|c|}
\hline \multicolumn{12}{|c|}{ Model Summary } \\
\hline \multirow[b]{2}{*}{ Phase } & \multirow[b]{2}{*}{ Group } & \multirow[b]{2}{*}{ Model } & \multirow[b]{2}{*}{$\mathrm{R}$} & \multirow[b]{2}{*}{ R Square } & \multirow[b]{2}{*}{$\begin{array}{c}\text { Adjusted R } \\
\text { Square }\end{array}$} & \multirow[b]{2}{*}{$\begin{array}{l}\text { Std. Error of } \\
\text { the Estimate }\end{array}$} & \multicolumn{5}{|c|}{ Change Statistics } \\
\hline & & & & & & & $\begin{array}{c}\text { R Square } \\
\text { Change }\end{array}$ & F Change & df1 & $\mathrm{df} 2$ & $\begin{array}{l}\text { Sig. F } \\
\text { Change }\end{array}$ \\
\hline \multirow[t]{2}{*}{ Pre-Test } & Experimental & 1 & $.757^{\mathrm{a}}$ & .573 & .390 & .46213 & .573 & 3.129 & 3 & 7 & .097 \\
\hline & Control & 1 & $.580^{\circ}$ & .336 & .052 & .57913 & .336 & 1.182 & 3 & 7 & .383 \\
\hline \multirow[t]{2}{*}{ Post-Test } & Experimental & 1 & $.931^{\mathrm{c}}$ & .867 & .811 & .48133 & .867 & 15.268 & 3 & 7 & .002 \\
\hline & Control & 1 & $.918^{\circ}$ & .843 & .776 & .29931 & .843 & 12.529 & 3 & 7 & .003 \\
\hline
\end{tabular}

a. Predictors: (Constant), Bills per day per square foot, CIP of essential products, Store Average Transaction Value

b. Dependent Variable: Profit per day per square foot

c. Predictors: (Constant), Bills per day per square foot, Store Average Transaction Value, CIP of essential products

\begin{tabular}{|c|c|c|c|c|c|c|c|c|}
\hline \multicolumn{9}{|c|}{ ANOVA $^{a}$} \\
\hline Phase & Group & Model & & $\begin{array}{l}\text { Sum of } \\
\text { Squares }\end{array}$ & df & Mean Square & $\mathrm{F}$ & Sig. \\
\hline \multirow[t]{6}{*}{ Pre-Test } & \multirow[t]{3}{*}{ Experimental } & \multirow[t]{3}{*}{1} & Regression & 2.005 & 3 & .668 & 3.129 & $.097^{\mathrm{b}}$ \\
\hline & & & Residual & 1.495 & 7 & .214 & & \\
\hline & & & Total & 3.500 & 10 & & & \\
\hline & \multirow[t]{3}{*}{ Control } & \multirow[t]{3}{*}{1} & Regression & 1.189 & 3 & .396 & 1.182 & $.383^{\mathrm{C}}$ \\
\hline & & & Residual & 2.348 & 7 & .335 & & \\
\hline & & & Total & 3.537 & 10 & & & \\
\hline \multirow[t]{6}{*}{ Post-Test } & \multirow[t]{3}{*}{ Experimental } & \multirow[t]{3}{*}{1} & Regression & 10.612 & 3 & 3.537 & 15.268 & $.002^{\mathrm{C}}$ \\
\hline & & & Residual & 1.622 & 7 & .232 & & \\
\hline & & & Total & 12.233 & 10 & & & \\
\hline & \multirow[t]{3}{*}{ Control } & \multirow[t]{3}{*}{1} & Regression & 3.367 & 3 & 1.122 & 12.529 & $.003^{\mathrm{c}}$ \\
\hline & & & Residual & .627 & 7 & .090 & & \\
\hline & & & Total & 3.994 & 10 & & & \\
\hline
\end{tabular}

a. Dependent Variable: Profit per day per square foot

b. Predictors: (Constant), Bills per day per square foot, CIP of essential products, Store Average Transaction Value

c. Predictors: (Constant), Bills per day per square foot, Store Average Transaction Value, CIP of essential products 


\begin{tabular}{|c|c|c|c|c|c|c|c|c|}
\hline \multicolumn{9}{|c|}{ Coefficients $^{a}$} \\
\hline \multirow[b]{2}{*}{ Phase } & \multirow[b]{2}{*}{ Group } & \multirow[b]{2}{*}{ Model } & & \multicolumn{2}{|c|}{ Unstandardized Coefficients } & \multirow{2}{*}{$\begin{array}{c}\text { Standardized } \\
\text { Coefficients } \\
\text { Beta }\end{array}$} & \multirow[b]{2}{*}{$t$} & \multirow[b]{2}{*}{ Sig. } \\
\hline & & & & B & Std. Error & & & \\
\hline \multirow[t]{8}{*}{ Pre-Test } & \multirow[t]{4}{*}{ Experimental } & \multirow[t]{4}{*}{1} & (Constant) & -6.777 & 4.045 & & -1.675 & .138 \\
\hline & & & CIP of essential products & 2.555 & 6.350 & .104 & .402 & .699 \\
\hline & & & $\begin{array}{l}\text { Store Average } \\
\text { Transaction Value }\end{array}$ & .001 & .002 & .199 & .699 & .507 \\
\hline & & & $\begin{array}{l}\text { Bills per day per square } \\
\text { foot }\end{array}$ & 261.739 & 117.955 & .659 & 2.219 & .062 \\
\hline & \multirow[t]{4}{*}{ Control } & \multirow[t]{4}{*}{1} & (Constant) & -12.824 & 8.192 & & -1.565 & .161 \\
\hline & & & CIP of essential products & 2.313 & 7.817 & .099 & .296 & .776 \\
\hline & & & $\begin{array}{l}\text { Store Average } \\
\text { Transaction Value }\end{array}$ & .003 & .002 & .575 & 1.766 & .121 \\
\hline & & & $\begin{array}{l}\text { Bills per day per square } \\
\text { foot }\end{array}$ & 528.196 & 448.007 & .415 & 1.179 & .277 \\
\hline \multirow[t]{8}{*}{ Post-Test } & \multirow[t]{4}{*}{ Experimental } & \multirow[t]{4}{*}{1} & (Constant) & 2.696 & 11.690 & & .231 & .824 \\
\hline & & & CIP of essential products & -14.239 & 11.458 & -.251 & -1.243 & .254 \\
\hline & & & $\begin{array}{l}\text { Store Average } \\
\text { Transaction Value }\end{array}$ & .000 & .005 & -.016 & -.090 & .931 \\
\hline & & & $\begin{array}{l}\text { Bills per day per square } \\
\text { foot }\end{array}$ & 355.735 & 63.830 & 1.077 & 5.573 & .001 \\
\hline & \multirow[t]{4}{*}{ Control } & \multirow[t]{4}{*}{1} & (Constant) & -19.987 & 8.966 & & -2.229 & .061 \\
\hline & & & CIP of essential products & -4.963 & 6.720 & -.138 & -.738 & .484 \\
\hline & & & $\begin{array}{l}\text { Store Average } \\
\text { Transaction Value }\end{array}$ & .009 & .004 & .364 & 2.203 & .063 \\
\hline & & & $\begin{array}{l}\text { Bills per day per square } \\
\text { foot }\end{array}$ & 469.524 & 82.904 & 1.002 & 5.663 & .001 \\
\hline
\end{tabular}

a. Dependent Variable: Profit per day per square foot

\section{Coefficient Correlations ${ }^{a}$}

\begin{tabular}{|c|c|c|c|c|c|c|c|}
\hline Phase & Group & Model & & & $\begin{array}{l}\text { Bills per day } \\
\text { per square } \\
\text { foot }\end{array}$ & $\begin{array}{l}\text { CIP of } \\
\text { essential } \\
\text { products }\end{array}$ & $\begin{array}{c}\text { Store Average } \\
\text { Transaction } \\
\text { Value }\end{array}$ \\
\hline \multirow[t]{12}{*}{ Pre-Test } & \multirow[t]{6}{*}{ Experimental } & \multirow[t]{6}{*}{1} & \multirow[t]{3}{*}{ Correlations } & $\begin{array}{l}\text { Bills per day per square } \\
\text { foot }\end{array}$ & 1.000 & .296 & -.498 \\
\hline & & & & CIP of essential products & .296 & 1.000 & -.104 \\
\hline & & & & $\begin{array}{l}\text { Store Average } \\
\text { Transaction Value }\end{array}$ & -.498 & -.104 & 1.000 \\
\hline & & & \multirow[t]{3}{*}{ Covariances } & $\begin{array}{l}\text { Bills per day per square } \\
\text { foot }\end{array}$ & 13913.291 & 221.745 & -.102 \\
\hline & & & & CIP of essential products & 221.745 & 40.317 & -.001 \\
\hline & & & & $\begin{array}{l}\text { Store Average } \\
\text { Transaction Value }\end{array}$ & -.102 & -.001 & $3.041 \mathrm{E}-6$ \\
\hline & \multirow[t]{6}{*}{ Control } & \multirow[t]{6}{*}{1} & \multirow[t]{3}{*}{ Correlations } & $\begin{array}{l}\text { Bills per day per square } \\
\text { foot }\end{array}$ & 1.000 & .389 & .325 \\
\hline & & & & CIP of essential products & .389 & 1.000 & .098 \\
\hline & & & & $\begin{array}{l}\text { Store Average } \\
\text { Transaction Value }\end{array}$ & .325 & .098 & 1.000 \\
\hline & & & \multirow[t]{3}{*}{ Covariances } & $\begin{array}{l}\text { Bills per day per square } \\
\text { foot }\end{array}$ & 200710.711 & 1362.412 & .225 \\
\hline & & & & CIP of essential products & 1362.412 & 61.102 & .001 \\
\hline & & & & $\begin{array}{l}\text { Store Average } \\
\text { Transaction Value }\end{array}$ & .225 & .001 & $2.394 \mathrm{E}-6$ \\
\hline \multirow[t]{12}{*}{ Post-Test } & \multirow[t]{6}{*}{ Experimental } & \multirow[t]{6}{*}{1} & \multirow[t]{3}{*}{ Correlations } & $\begin{array}{l}\text { Bills per day per square } \\
\text { foot }\end{array}$ & 1.000 & -.539 & .223 \\
\hline & & & & CIP of essential products & -.539 & 1.000 & .364 \\
\hline & & & & $\begin{array}{l}\text { Store Average } \\
\text { Transaction Value }\end{array}$ & .223 & .364 & 1.000 \\
\hline & & & \multirow[t]{3}{*}{ Covariances } & $\begin{array}{l}\text { Bills per day per square } \\
\text { foot }\end{array}$ & 4074.283 & -394.213 & .076 \\
\hline & & & & CIP of essential products & -394.213 & 131.284 & .022 \\
\hline & & & & $\begin{array}{l}\text { Store Average } \\
\text { Transaction Value }\end{array}$ & .076 & .022 & $2.831 \mathrm{E}-5$ \\
\hline & \multirow[t]{6}{*}{ Control } & \multirow[t]{6}{*}{1} & \multirow[t]{3}{*}{ Correlations } & $\begin{array}{l}\text { Bills per day per square } \\
\text { foot }\end{array}$ & 1.000 & -.468 & .086 \\
\hline & & & & CIP of essential products & -.468 & 1.000 & .325 \\
\hline & & & & $\begin{array}{l}\text { Store Average } \\
\text { Transaction Value }\end{array}$ & .086 & .325 & 1.000 \\
\hline & & & \multirow[t]{3}{*}{ Covariances } & $\begin{array}{l}\text { Bills per day per square } \\
\text { foot }\end{array}$ & 6873.044 & -260.996 & .029 \\
\hline & & & & CIP of essential products & -260.996 & 45.162 & .009 \\
\hline & & & & $\begin{array}{l}\text { Store Average } \\
\text { Transaction Value }\end{array}$ & .029 & .009 & $1.638 \mathrm{E}-5$ \\
\hline
\end{tabular}

a. Dependent Variable: Profit per day per square foot 
Residuals Statistics ${ }^{\mathrm{a}}$

\begin{tabular}{|c|c|c|c|c|c|c|c|}
\hline Phase & Group & & Minimum & Maximum & Mean & Std. Deviation & $\mathrm{N}$ \\
\hline \multirow[t]{8}{*}{ Pre-Test } & \multirow[t]{4}{*}{ Experimental } & Predicted Value & -1.3764 & -.0095 & -.8336 & .44776 & 11 \\
\hline & & Residual & -.70068 & .67640 & .00000 & .38665 & 11 \\
\hline & & Std. Predicted Value & -1.212 & 1.841 & .000 & 1.000 & 11 \\
\hline & & Std. Residual & -1.516 & 1.464 & .000 & .837 & 11 \\
\hline & \multirow[t]{4}{*}{ Control } & Predicted Value & -2.1609 & -1.0024 & -1.7264 & .34484 & 11 \\
\hline & & Residual & -.72369 & .71429 & .00000 & .48453 & 11 \\
\hline & & Std. Predicted Value & -1.260 & 2.100 & .000 & 1.000 & 11 \\
\hline & & Std. Residual & -1.250 & 1.233 & .000 & .837 & 11 \\
\hline \multirow[t]{8}{*}{ Post-Test } & \multirow[t]{4}{*}{ Experimental } & Predicted Value & -.6020 & 2.5181 & .6727 & 1.03013 & 11 \\
\hline & & Residual & -.62563 & .57184 & .00000 & .40271 & 11 \\
\hline & & Std. Predicted Value & -1.237 & 1.791 & .000 & 1.000 & 11 \\
\hline & & Std. Residual & -1.300 & 1.188 & .000 & .837 & 11 \\
\hline & \multirow[t]{4}{*}{ Control } & Predicted Value & -1.1407 & .5450 & -.2809 & .58027 & 11 \\
\hline & & Residual & -.31338 & .39157 & .00000 & .25042 & 11 \\
\hline & & Std. Predicted Value & -1.482 & 1.423 & .000 & 1.000 & 11 \\
\hline & & Std. Residual & -1.047 & 1.308 & .000 & .837 & 11 \\
\hline
\end{tabular}

a. Dependent Variable: Profit per day per square foot 